Article

\title{
A Stitch in Time Saves Nine: Nexus between Critical Delay Factors, Leadership Self-Efficacy, and Transnational Mega Construction Project Success
}

\author{
Umer Zaman ${ }^{1, * \mathbb{D}}$, Laura Florez-Perez ${ }^{2}$, Saba Abbasi ${ }^{3}$, Shahid Nawaz ${ }^{4}$, Pablo Farías ${ }^{5}$ and Mahir Pradana ${ }^{6}$ (D) \\ 1 Endicott College of International Studies (ECIS), Woosong University, Daejeon 34606, Korea \\ 2 Bartlett School of Sustainable Construction, Faculty of the Built Environment, \\ University College London (UCL), London WC1E 6BT, UK; 1.florez@ucl.ac.uk \\ 3 Management Science Department, National University of Modern Languages (NUML), \\ Islamabad 44000, Pakistan; saba.abbasi@numl.edu.pk \\ 4 Department of Management Sciences, Islamia University Bahawalpur (IUB), Bahawalpur 63100, Pakistan; \\ dr.shahid@iub.edu.pk \\ 5 Departamento de Administración, Facultad de Economía y Negocios, Universidad de Chile, \\ Santiago 8330015, Chile; pfarias@fen.uchile.cl \\ 6 Department of Business Administration, Faculty of Communication and Business, Telkom University, \\ Batu 40257, Indonesia; mahirpradana@telkomuniversity.ac.id \\ * Correspondence: umerzaman@endicott.ac.kr
}

check for updates

Citation: Zaman, U.; Florez-Perez, L.; Abbasi, S.; Nawaz, S.; Farías, P.; Pradana, M. A Stitch in Time Saves Nine: Nexus between Critical Delay Factors, Leadership Self-Efficacy, and Transnational Mega Construction Project Success. Sustainability 2022, 14, 2091. https://doi.org/10.3390/ su14042091

Academic Editors: Willie Tan and Robert Lee Kong Tiong

Received: 23 December 2021 Accepted: 10 February 2022 Published: 12 February 2022

Publisher's Note: MDPI stays neutral with regard to jurisdictional claims in published maps and institutional affiliations.

Copyright: () 2022 by the authors Licensee MDPI, Basel, Switzerland. This article is an open access article distributed under the terms and conditions of the Creative Commons Attribution (CC BY) license (https:// creativecommons.org/licenses/by/ $4.0 /)$.

\begin{abstract}
Delay factors are frequent in the construction industry globally, resulting in significant overruns in project cost and time. In context, megaprojects can be more prone to critical delays, hence, demanding a high degree of self-confident leadership. Despite the continuous scholarly attempts to examine mega construction project success, the underlying role of critical delay factors and leadership self-efficacy has been largely overlooked. Hence, to address these rarely examined linkages, the present study empirically explored the effects of critical delay factors (CDFs) on transnational mega construction project (TMCP) success with the moderating influence of leadership self-efficacy (LSE). Based on a study sample $(\mathrm{N}=211$ ) extracted from the China-Pakistan Economic Corridor, the hypothesized relationships were tested through partial least squares-structural equation modeling. The study included nine critical delay factors and three subdimensions of TMCP success, derived from previous research. The findings revealed a negative relationship between CDFs and TMCP success, as a $1 \%$ increase in CDFs triggered a $28.8 \%$ negative change in TMCP success. A positive moderating effect of LSE on the relationship between CDFs and TMCP success was also empirically supported, as $1 \%$ increase in LSE resulted in $18.4 \%$ positive change in TMCP success. The present study bridges the fragmented literature on critical delay factors in the global construction industry, megaproject success, and project leadership, by providing the first empirical evidence linking these potential relationships. Moreover, the present study also provides an extension to existing studies to identify the role of CDFs and LSE in impacting multi-faceted success (i.e., management success, ownership success, and investment success) in mega construction projects.
\end{abstract}

Keywords: transnational mega construction project; critical delay factors; project leader's self-efficacy; mega construction project success; China-Pakistan Economic Corridor

\section{Introduction}

Mega construction projects are considered the backbone of the construction industry and contribute to vast amounts of revenue to global economies. Typically, megaprojects are large-scale projects with huge investments (valuing over USD 1 billion) and complex technological and organizational settings [1]. About $6 \%$ of the global gross domestic product is yielded from construction developments, and in part, from megaprojects. The nature of 
megaprojects is either local or global, and these are the barometers of the construction industry's health $[1,2]$. Along with the rapid increase in global construction industry outputs, transnational projects' opportunities have also increased. The economic globalization of the last two decades has changed the geostrategic preferences so that governments around the world can profit from economic synergy [1]. With the change in global trends, countries have also changed and redefined their policies and preferences to defend their interests through collaboration with transnational projects [1,2].

Transnational projects are innovative forms of organization, adapted to changing competition, and are functionally and nationally heterogeneous [2]. In transnational projects, project teams are not entirely co-located, yet need to be coordinated to integrate new knowledge and technology into products and services on a larger scale. The increasing importance of networks among organizational units and people is one of the main characteristics of transnational projects $[1,3]$. When transnational projects are large in scale, transnational megaprojects emerge. These projects are significant for economic growth, social development, and urbanization strategies. Still, mega transnational projects face many challenges such as decision-related risks, cost overruns, performance inefficiencies, and environmental damages [3]. These challenges call for competent and far-sighted leadership [1,4].

Leadership is fundamentally a process of organizational influence directed towards achieving desired objectives. For this, leaders successfully execute the behaviors that are needed to persuade groups of people and initiate change [4]. Change requires persistence and determination and an individual's self-judgment of its ability to achieve the performance required (or self-efficacy) is a measure of this ability. Leadership self-efficacy (LSE) is a proximal variable in a challenging situation to estimate a leader's coping ability, which in a way is an outcome of a leader's perceived ability to control situations, make choices, orchestrate people, and perform with the available resources in spite of obstacles [5]. The higher the self-efficacy in the leadership, the higher the chances of project success.

Project success can be linked with multiple factors in any organization. Project success is a relative term for different stakeholders. Project ownership, project investment, and project management success are three relevant dimensions to analyze the success of mega construction projects. However, it is known that project success can be negatively affected by project delays. Project delays are caused by one or more project groups and resources, which include the project owner, contractor, designer, materials, equipment, labor, and external factors [6]. Delays might occur simultaneously or separately. In transnational megaprojects, the effects of delays can prove catastrophic given their large scale and organizational units, which may lead to business loss, bankruptcy, and even government disturbances. The megaproject management teams (especially in the global construction industry) operate in multiple directions simultaneously due to an increased scope of work. Working with several facets of internal and external environments at the same time, the megaproject teams face inconsistencies that may usually lead to an impact on project goals or even success on a scale of bad to worse. These inconsistencies also include delays (i.e., delays in technical, managerial, operational, legislative, and resource planning activities), which are highly critical, as they increase megaproject time and eventually emerge into a megaproject financing crisis $[1,2,6]$. However, with effective management through selfconfident leadership, the negative effects of potential delays and inconsistencies can be invalidated. Timely identification of critical delay factors and their integration into project plans can help navigate megaprojects towards success despite various challenges [2,6]. Self-confident leaders can creatively lead initiatives and make timely decisions to reverse and/or minimize the negative impact of delay factors on megaprojects' performance and success [4-6]. Despite theoretical underpinning, there is rare empirical evidence supporting the underlying relationships between CDFs, LSE, and TMCP success $[2,6]$. Therefore, the present study aimed to explore the impacts of $\mathrm{CDFs}$ on $\mathrm{TMCP}$ success and the moderating role of LSE. By studying the China-Pakistan Economic Corridor (CPEC), this study offers insights on critical delay factors in megaprojects and identifies their role in the multi- 
faceted success (i.e., project management success, project investment success, and project ownership success) in transnational mega construction projects $[1,5,6]$.

\section{Theoretical Background and Hypothesis Development}

\subsection{Transnational Mega Construction Project Success}

The existing literature on project success distinctly defines success criteria and critical success factors in view of project management dynamics [7]. Project success criteria involve project objectives that are dependent on stakeholders' perspectives. Critical success factors, on the other hand, focus on the circumstances and the atmosphere of projects [8]. Project success was initially confined to the traditional measurement of the project evaluation (i.e., time, cost, and quality). However, Radujković and Sjekavica [9] consider project management competence, organizational elements, and management methodologies among other project success factors. In addition to project management success, further human factors of project success are project ownership success and project investment success linked with the value generated by the project and the fulfillment of project objectives, which is subjective to the nature of projects. Project ownership success and project investment success are more inclusive since these two dimensions are measured through the value generated by the product from a funding point of view [10].

Construction projects are complex and require large economic investments to sustain and produce the expected outputs [1,11]. Transnational mega construction projects (TMCP) are even more complex and involve critical elements, including multiple international stakeholders, ample number of resources, and huge monetary investments [12,13]. The scale of TMCP is massive and consequently, these projects may have a massive impact on the governments and organizations involved. Such projects' success is critical for nations, given that failures can result in cost overruns, time overruns, technical failures, business losses, contingencies in quality, and even more devastating consequences, such as bankruptcy and government disturbances [12]. If TMCP's are successful, then these have the potential to positively impact the involved nations economically, socially, and politically $[11,14]$. The TMCP's nature is complex and challenging due to the projects' scale and impact on governments and millions of people. Along with the primary success metrics of cost, time, and quality, the success of TMCPs involves multiple other dimensions, i.e., client satisfaction, economic gain, environmental impact, resource utilization, conflict management, and risk management [15].

Zwikael and Meredith [16] defined project management success, project ownership success, and project investment success distinctly. There is a strong relationship between project success and project management success. Generally, project success includes the overall performance of project objectives. In other words, project success is not an indicator of individual performance as it encompasses multiple dimensions. TMCP success also focuses on the stakeholders' satisfaction and the project objectives, which are different in multiple aspects from standard construction projects, including proper utilization of technology, consideration of cultural differences, adherence to the project timeline goals, cost-effectiveness, and recognition of stakeholders' expectations at large [17]. To ensure the successful completion of project goals and objectives effectively, TMCPs need to prioritize certain critical success factors, including knowledge of cultural preferences, effective resource consumption, stakeholder satisfaction, performance assessments at each stage of the project life cycle, and project structure management $[18,19]$.

\subsection{Critical Delay Factors}

During their life cycle, projects might face delays in different stages, from project initiation through project end. Delays in construction projects can be defined as crossing the time threshold in project delivery or other project milestones. Project delays that impact a project's deadline are defined as the critical delay that occurs due to several factors. The critical delay factors vary based on project scope, areas, and industries. Various scholars have discussed delaying aspects in construction projects and the subject is still a crucial topic 
of research among project management researchers globally $[6,20,21]$. Mismanagement in areas related to the project owner, project team, project equipment, and project procurement leads to major delays in timely project execution [22]. Some prominent reasons for delays identified by researchers are finance-related issues, indecisiveness in planning, design and scope incompetency, and communication or coordination problems. Some other reasons for delays include environmental concerns, resource deficit, performance, and contractor incompetency.

The delays originating from the malfunction in areas related to design, consultancy, contract, labor, material, equipment, and procurement are internal sources of delays. According to Ansah and Sorooshian [22], the teams that inflict delays in the project include contractors, consultants, clients, and designers. Amongst the many categories of internal delays, the delays caused by the inefficiency of the owner and their team (i.e., design flaws, specifications) are owner-specific delays. Owner-related delays include changes in design orders [6] from owners and their teams, which require additional time and resources. Generally, the delays associated with project design involve the designers' skill and perception of how the project is designed with the specified materials and capacities. Flawed design and shortcomings in specifications usually can be addressed, but cause delays in projects. According to a survey-based study on reasons for delays relating to managers, advisors, and contractors in construction projects, "change order" was the major reason for delays in Saudi construction projects, among other 73 outlined reasons [6].

The consultant-specific delays involve changes in the project's scale, testing and site investigation delays, reviews and authorization delays, unrest between design engineers or contractors, and consultants [23]. The contractor-specific delays entail dated technology, team's inability to carry out the project, team's lack of experience, inadequate investigation, lack of supervision, ineffective communication, and poor planning [24]. Other than the project participants, the procurement of projects [25] in the construction industry also engage in risks due to interruptions. This factor is further categorized as material-, labor-, and equipment-related delays. Material-related factors involve poor quality of material, material delivery delays, and incorrect estimation of required material. Labor-related factors that cause project delays include shortage of labor [26], lack of labor training, low labor productivity [27], risk of disputes, and labor's unfamiliarity with modern design techniques and new technology [28]. Additionally, the risk of inadequate equipment due to bad estimation or late delivery [29] and obsolete equipment [30] can halt the project progress delaying the completion of the project with the equipment-related factors. Apart from internal critical delay factors, projects also have to deal with some external sources of delays, i.e., delays in obtaining permits from government bodies, natural calamities, and weather conditions [31]. A recent review of critical delay factors in construction can be found in Yap et al. [32].

\subsection{Leadership Self-Efficacy}

Leaders of organizations are described as goal-oriented, highly passionate, practical, perseverant, problem solvers, and decision makers [33]. Self-efficacy is an individual's estimation of their own ability to orchestrate performance through executing the behaviors that are needed to achieve the desired outcomes [34]. It is assumed that a leader can exert influence on a group of people or an organization to guide, shape, and encourage engagement and cooperation to achieve change [35]. A leader's role in a changing environment defines the way an organization sets its goals and achieves these in a certain period. According to research carried out on leadership self-efficacy, there is no one way of defining leadership self-efficacy (LSE) due to the very diverse nature of leadership. However, it can be precisely summed up as a process where a leader influences their team to achieve a common goal [36]. LSE can be described as the self-efficacy behavior of an individual towards their ability to lead and the belief that they could accomplish the leadership roles in an organization. 
The interchangeability of leadership self-efficacy (LSE) and leadership effective taxonomies have been studied in the past. Although LSE is considered a latent construct in some studies, it is a more fine-grained behavioral domain (Anderson et al., 2008). High LSE in executives can lead to innovative ideas and exceptional outcomes. LSE's importance and impact in several organizations across different industries have been studied by scholars previously [37-39]. LSE's concept has various facets, including personal realization, mediated practice, verbal encouragement, and functional influence [40]. There is also evidence of LSE manifesting in subordinates. Redmond et al. [41] state that LSE can prompt subordinate's activities more effectively in problem-solving situations, which leads to high performance and commitment [39]. Timely decision making, mentorship, problem solving, and knowledge of managerial domains are some of the top leadership abilities.

A number of studies [42-46] show that a leader is assumed to possess self-efficacy, dedication, and the ability to persevere in difficult times with great leadership skills. High LSE is believed to positively impact an individual's performance as a leader [46]. It has been studied in light of its effects on many other organizational aspects. Ali et al. [47] studied the LSE and leadership effectiveness with the mediating effect of task complexity. The results state that LSE directly affects leadership effectiveness, and it can be beneficial for an organization to have high leadership efficacy in its leaders. A leader with high LSE not only believes in their ability that others think they possess, but also believes that they can do many things with their skills. A leader with high LSE tends to have high ambitions, better planning skills, greater credibility, and greater perseverance [37]. Self-efficacy is a quite reasonable tool to predict the performance of leaders in complex tasks. Ng et al. [48] discuss the relationship of leader effectiveness with personality traits and describe LSE as a meditating tool between the two. They stressed the need to consider the situational context of leaders while evaluating the relationship of personality and effectiveness with LSE [49]. Burns [5] assessed the low and high LSE of a leader and its interaction with situational strength and their impact on stress appraisal. The self-efficacy of a project manager is an indicator of how the project will perform or, in other words, the manager's performance [44]. Leaders can infuse efficient ideas, passion, and vision in an organizational environment in addition to their individual characteristics and skills. Previous theoretical research indicates that the high self-efficacy of a leader proves to be rewarding for his leadership motivation [42], as well as the productivity of sub-workers [39,50,51]. The discussion of high LSE and effective leadership can be directed towards its relationship and impacts on project success.

\subsection{Critical Delay Factors (CDFs) and TMCP Success}

On-time delivery of a project is one of the three traditional project performance measures (the three being time, cost, and quality). According to Shrivastava et al. [52], completing a project on scheduled time is the first building block of the project success framework, followed by the other two. Any disruption in time halts the further execution of the project. The time factor affects the cost factor, which significantly influences the project performance [53]. The factors that cause delays in various aspects of the project affect project success domains such as project management success, project ownership success, and investment success. Project management success is incredibly dependent on the contractor and the management team's performance [48]. These teams are responsible for project execution throughout the end resulting in either a success or a failure. The assessment of project management success is carried through the traditional triple factors of project success. Sambasivan and Soon [21] conducted a survey to study the cause-andeffect dimension of delays in construction projects and identified ten causes of delay (by using correlation), including improper planning, poor management from the contractor's end, incompetent contractor, fiscal deficit, insufficient material, communication barriers, construction shortcomings, labor supply, inadequate equipment, and lack of coordination with subcontractors. Project management success depends hugely on the decision-making quality of project teams. The ability to meet client requirements is also an outcome of 
team effectiveness, given that the managers decide the success of their project through the satisfaction of the project objectives. Project ownership success considers realizing all target benefits. Again, time overruns due to critical delay factors (CDFs), such as design changes, equipment, or material shortages, among others, can affect project ownership success, and cost overrun can influence the project investment success negatively.

The success of stakeholder dimensions of projects - manager, owner, and investor-is influenced by multiple CDFs in one way or another. Previous research on delay factors in construction management suggests that identifying delay factors and their effects on project performance is crucial to successfully managing projects. The acknowledgment of delay factors can help reduce their impact on project management success by their early control [54]. Moreover, the relationship of CDFs with the project performance in different domains, be it management-related, owner-related, or investment-related, has been discussed. By carefully analyzing the effects of the delays on projects, we build our first hypothesis as follows:

\section{Hypothesis 1 (H1). CDFs negatively impact the TMCP success.}

\subsection{Moderating Effects of Leadership Self-Efficacy (LSE)}

Mega construction projects are long-scale, long-term, and extremely complex projects which involve a huge deal of resources and stakeholders. The leaders of projects greatly impact the functioning of a project team [2]. The ability of a leader to adapt to change and their self-efficacy is key to effective leadership [42]. Self-efficacy in leaders has been proven to influence project participants' motivation and performance in a positive manner [55]. The performance of stakeholders is a critical success factor that cannot be ignored. The role of the manager, contractor, consultants, and other participants determines the individuals' performance and adds to the overall success of a project. Leaders can motivate and encourage sub-workers to create value for the project through maximum productivity.

The LSE of a manager is the most pervasive factor among the leadership personality traits. It aims to provide the basis for all other operational mechanisms for project completion and success [34]. An empirical study on the relationship between the manager's self-efficacy and employee engagement suggests that LSE is a partial meditator of the relationship between managers' engagement and the employees. It also indicated a positive influence on manager's effectiveness [56]. Hannah et al. [57] proposed a multi-level framework of leader, follower, and combined efficacies, which indicates that growth-oriented leaders instill the same values in the teams they lead. Seibert et al. [58] studied the relationship of development experiences with leadership effectiveness, while mentor network and leadership self-efficacy acted as mediators. The study reveals a positive indirect link between leadership effectiveness and promotability. A leader with high self-efficacy handles critical delay factors more effectively, which ultimately reduces negative impacts, thus increasing the opportunities for success (i.e., TMCP success). Importantly, in order to mitigate the negative risks associated with critical delays in megaprojects, leadership self-efficacy is central to finetune megaproject planning and execution by timely responding to the hidden signals, conditions, and implications of foreseen delays [4,6]. A high level of leadership self-efficacy provides the force to deal with the trials and pursue challenging opportunities. Efficacy promotes effective engagement, adaptability, and flexibility to change in complex organizational contexts, especially megaprojects $[2,57]$. Through investigating the construct of leadership self-efficacy and its role in team performance, it is safely supposed that LSE improves job satisfaction and productivity of project participants resulting in better overall performance. We propose the second hypothesis for the study here, as follows:

Hypothesis 2 (H2). LSE significantly moderates the negative effects of CDFs on TMCP success. 


\section{Methods}

\subsection{Sampling and Procedure}

Empirical research, based on a cross-sectional survey design, was applied to analyze the relationship between CDFs and TMCP success, involving LSE as a potential moderator [59]. The study data was collected from mega construction project officials representing the population of construction project management practitioners and experts (e.g., engineers, technicians, surveyors, architects, and site managers) associated with the China-Pakistan Economic Corridor (CPEC) in Pakistan. CPEC is a transnational mega construction project, developed to profit both China and Pakistan, and help these two countries achieve their economic interests and enhance common development opportunities, as a consequence of globalization-influenced trends. The CPEC comprises nationwide infrastructure development in Pakistan (e.g., airports, railway lines, highways, seaports, motorways, and bridges), including projects related to energy for electricity production and construction of transmission lines.

The surveyed entities were directly associated with the CPEC megaproject, involving project teams (e.g., operational teams, technical teams, and quality teams), project owners, and stakeholders (e.g., organizational managers, public officials, and subcontractors). Two prescreening questions were set at the beginning of the survey, i.e., (1) Are you directly associated with the CPEC megaproject? (Responses: Yes or No), and (2) Do you have a decision-making role in the CPEC megaproject (e.g., planning, execution, and evaluation)? (Responses: Yes or No). The surveyed responses of only those volunteering participants $(\mathrm{N}=211)$ who confirmed "Yes" for both prescreening questions were included in the present study, while all others were disregarded. Considering the heightened complications of COVID-19-imposed restrictions and limited access to the CPEC officials, the standardized online survey invitation was circulated through direct emails (identified through the official CPEC website and linked websites to CPEC-related megaprojects), and social networking platforms (especially LinkedIn).

By applying the non-probabilistic (convenience-based) sampling technique, the study attained an adequate sample size $(\mathrm{N}>200)$ for partial least squares-structural equation modeling (PLS-SEM) as all survey questions (labeled as mandatory) were successfully completed by all respondents $(\mathrm{N}=211)$. Hence, the present study gained benefits through the widely known advantages of non-probabilistic sampling (e.g., cost and time effective, high motivation, and response rate), especially considering the complications of data collection during the COVID-19 pandemic. The selected sampling method also facilitated shortlisting and selecting participants with adequate knowledge of the CPEC mega construction project. To prevent the common method bias, the study employed procedural remedies (e.g., ensuring anonymity, confidentiality, clarifications, and feedback to the participants, also not sharing with the respondents any information about the conceptual model and hypothesized relationships). Additionally, to mitigate the chances of further methodological weaknesses, we chose the most relevant and carefully constructed (adapted scales) items only. The adapted scales for CDFs, LSE, and TMCP success (as explained in detail in the following Section 3.2) ensured adequate reliability and validity to measure these intended constructs, as confirmed by prior studies [6,48,60-62].

\subsection{Measures}

\subsubsection{Critical Delay Factors (CDFs)}

The scale for this measure was adapted from the analyses by Assaf and Al-Hejji [6] and Gondia et al. [60]. This measure assessed the major factors of delays in construction projects and divided them into nine groups: project-related delays, owner-associated delays, design-associated delays, consultant-associated delays, contractor-associated delays, laborassociated delays, equipment-associated delays, material-associated delays, and external delays. The 9 groups comprised 59 items as a whole. These items were measured through the adapted scales, which considered the degree of severity and frequency of each item's occurrence on a 5 -point Likert scale $(1=$ little to $5=$ extreme $)$ in the project environment. 


\subsubsection{Leadership Self-Efficacy (LSE)}

The measurement scale of LSE was applied from Burns [5], Chemers et al. [61], and $\mathrm{Ng}$ et al. [48], which consisted of 11 items [5]. The scale comprised key characteristics of leadership self-efficacy in different aspects, e.g., task coordination, planning skill, encouraging team, setting directions, and communication ability. The LSE adapted scale assessed these characteristics by asking about the performance of leadership on a 5-point Likert scale, where: 1 indicated "strongly disagree" and 5 indicated "strongly agree". This scale was acknowledged by $\mathrm{Ng}$ et al. [48] and Burns [5] for evaluation of LSE in organizations.

\subsubsection{TMCP Success}

A multidimensional scale was implemented to evaluate project success. This scale was developed and validated by Musawir et al. [62]. The scale evaluated the three-dimensional success model of project management success, project ownership success, and project investment success. The project success framework developed by Musawir et al. [62] comprised of questions related to each dimension presenting a total of 11 items, including 5 items for project management success, 3 items for project ownership success, and 3 items for project investment success. In the present study, all items were scaled on a 5-point Likert scale, ranging from $1=$ strongly disagree to $5=$ strongly agree.

\subsubsection{Data Analysis}

The present study used the latest software version for PLS-SEM (widely known as Smart PLS) for data analysis. SEM is extensively used by practitioners and researchers in various industries for its strength of predictive qualities, whereas PLS-SEM is one of its two major generations (i.e., CB-SEM and PLS-SEM) [63]. PLS-SEM is a useful multivariate approach for exploring and predicting complex models [64,65]. Since the study is based on a cross-sectional survey, the measurement model component of PLS-SEM was used to examine the individual constructs, whereas the structural model component examined the cause-effect relationship between the latent constructs. To confirm the consistency and precision of the measurement instruments, the reliability, convergent validity, and discriminant validity assessment for all scales were ensured. PLS-SEM analyzed the measurement model and the structural model of the studied constructs, after statistical estimations for inspecting common method bias (CMB) $[66,67]$.

\section{Results}

\subsection{Measurement Model}

The PLS measurement model identified that all latent variables (CDFs, LSE, TMCP success) have Cronbach's alpha and composite reliability values greater than 0.70 , which is over and above the minimum threshold, confirming the reliability of the study constructs $[68,69]$. Moreover, the average variance extracted (AVE) is above 0.5 , which confirms the convergent validity and is formerly ensured by using each construct's factor loading value being higher than $0.60[70,71]$ (see Table 1). Figure 1 presents the measurement model of TMCP success. As presented in Table 2, the Heterotrait-Monotrait ratio (HTMT) approach is used for discriminant validity assessment. Note that the values shown in Table 3 are lower than the recommended threshold (i.e., 0.90), indicating the confirmation of discriminant validity in the study constructs [72]. Tables 1 and 2 present the construct reliability and discriminant validity assessment results, respectively, and validate the measurement instrument's consistency. To statistically determine the possibility of common method bias, the present study employed the widely known Harman's single factor (HSF) test [66,67]. The HSF test revealed that $\mathrm{CMB}$ was clearly non-existent as the total estimated variance (as explained by a single factor) was just $30.67 \%$ (i.e., much lower than the cutoff value of $50 \%$ ) $[66,67]$. 
Table 1. Construct reliability and validity $(\mathrm{N}=211)$.

\begin{tabular}{|c|c|c|c|c|c|}
\hline & Items & Loading & Cronbach's Alpha & Composite Reliability & AVE \\
\hline \multirow[t]{6}{*}{ Project-Related Delay } & CDF1 & 0.705 & 0.845 & 0.887 & 0.571 \\
\hline & CDF2 & 0.806 & & & \\
\hline & CDF3 & 0.860 & & & \\
\hline & CDF4 & 0.756 & & & \\
\hline & CDF5 & 0.815 & & & \\
\hline & CDF6 & 0.556 & & & \\
\hline \multirow[t]{6}{*}{ Owner-Related Delay } & CDF7 & 0.713 & 0.866 & 0.900 & 0.600 \\
\hline & CDF9 & 0.744 & & & \\
\hline & CDF11 & 0.746 & & & \\
\hline & CDF12 & 0.836 & & & \\
\hline & CDF13 & 0.840 & & & \\
\hline & CDF14 & 0.759 & & & \\
\hline \multirow[t]{3}{*}{ Design-Related Delay } & CDF17 & 0.897 & 0.846 & 0.904 & 0.759 \\
\hline & CDF18 & 0.833 & & & \\
\hline & CDF19 & 0.882 & & & \\
\hline \multirow[t]{6}{*}{ Consultant-Related Delay } & CDF21 & 0.832 & 0.911 & 0.931 & 0.692 \\
\hline & CDF22 & 0.793 & & & \\
\hline & CDF23 & 0.832 & & & \\
\hline & CDF24 & 0.842 & & & \\
\hline & CDF25 & 0.879 & & & \\
\hline & CDF26 & 0.812 & & & \\
\hline \multirow[t]{6}{*}{ Contractor-Related Delay } & CDF32 & 0.792 & 0.906 & 0.929 & 0.686 \\
\hline & CDF33 & 0.891 & & & \\
\hline & CDF34 & 0.853 & & & \\
\hline & CDF35 & 0.880 & & & \\
\hline & CDF36 & 0.858 & & & \\
\hline & CDF37 & 0.676 & & & \\
\hline \multirow[t]{4}{*}{ Labor-Related Delay } & CDF38 & 0.912 & 0.921 & 0.944 & 0.808 \\
\hline & CDF39 & 0.867 & & & \\
\hline & CDF40 & 0.909 & & & \\
\hline & CDF41 & 0.906 & & & \\
\hline \multirow[t]{5}{*}{ Material-Related Delay } & CDF42 & 0.826 & 0.860 & 0.900 & 0.644 \\
\hline & CDF43 & 0.853 & & & \\
\hline & CDF44 & 0.851 & & & \\
\hline & CDF45 & 0.780 & & & \\
\hline & CDF46 & 0.691 & & & \\
\hline \multirow[t]{5}{*}{ Equipment-Related Delay } & CDF47 & 0.891 & 0.897 & 0.924 & 0.710 \\
\hline & CDF48 & 0.890 & & & \\
\hline & CDF49 & 0.842 & & & \\
\hline & CDF50 & 0.834 & & & \\
\hline & CDF51 & 0.749 & & & \\
\hline \multirow[t]{6}{*}{ External-Related Delay } & CDF52 & 0.738 & 0.869 & 0.902 & 0.608 \\
\hline & CDF53 & 0.825 & & & \\
\hline & CDF54 & 0.714 & & & \\
\hline & CDF55 & 0.711 & & & \\
\hline & CDF56 & 0.819 & & & \\
\hline & CDF57 & 0.856 & & & \\
\hline \multirow[t]{8}{*}{ Leadership Self-Efficacy } & LSE1 & 0.784 & 0.948 & 0.956 & 0.731 \\
\hline & LSE2 & 0.840 & & & \\
\hline & LSE4 & 0.901 & & & \\
\hline & LSE5 & 0.898 & & & \\
\hline & LSE6 & 0.904 & & & \\
\hline & LSE7 & 0.794 & & & \\
\hline & LSE8 & 0.852 & & & \\
\hline & LSE10 & 0.859 & & & \\
\hline
\end{tabular}


Table 1. Cont.

\begin{tabular}{|c|c|c|c|c|c|}
\hline & Items & Loading & Cronbach's Alpha & Composite Reliability & AVE \\
\hline \multirow[t]{5}{*}{ Project Management Success } & TMCP1 & 0.798 & 0.850 & 0.893 & 0.626 \\
\hline & TMCP2 & 0.772 & & & \\
\hline & TMCP3 & 0.821 & & & \\
\hline & TMCP4 & 0.806 & & & \\
\hline & TMCP5 & 0.757 & & & \\
\hline \multirow[t]{3}{*}{ Project Ownership Success } & TMCP6 & 0.834 & 0.792 & 0.878 & 0.707 \\
\hline & TMCP7 & 0.873 & & & \\
\hline & TMCP8 & 0.814 & & & \\
\hline \multirow{3}{*}{ Project Investment Success } & TMCP9 & 0.853 & 0.818 & 0.892 & 0.733 \\
\hline & TMCP10 & 0.839 & & & \\
\hline & TMCP11 & 0.877 & & & \\
\hline
\end{tabular}

Notes: TMCP—transnational mega construction project success; CDF-critical delay factors; LSE-leadership self-efficacy; AVE—average variance extracted.

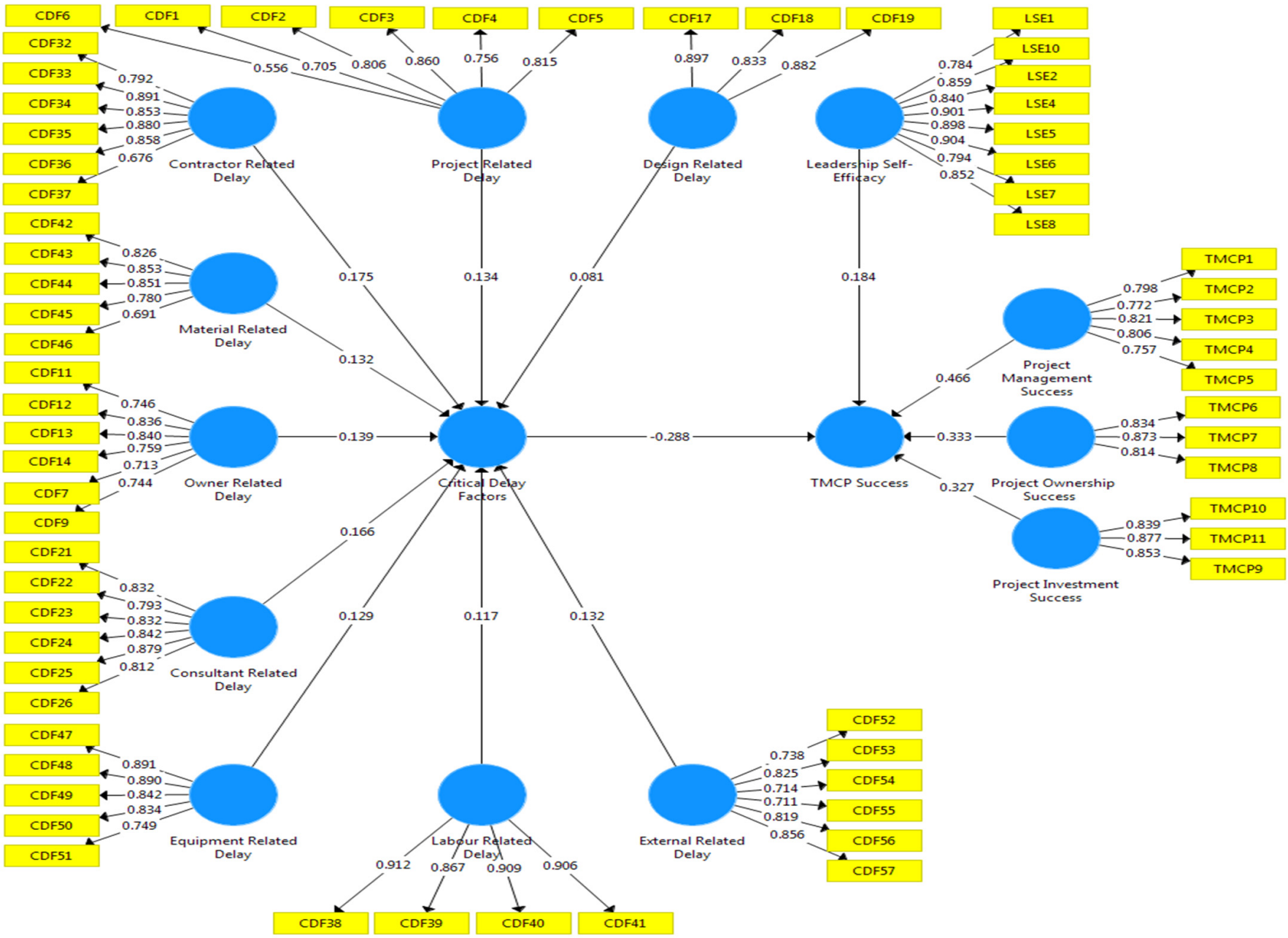

Figure 1. Measurement model of TMCP success.

Table 2. Discriminant validity (HTMT approach) $(\mathrm{N}=211)$.

\begin{tabular}{|c|c|c|c|c|c|c|c|c|c|c|c|c|c|}
\hline & POS & CRD & CoRD & DRD & ERD & ExRD & LRD & LSE & MRD & ORD & PIS & PMS & PRD \\
\hline POS & & & & & & & & & & & & & \\
\hline CRD & 0.201 & & & & & & & & & & & & \\
\hline CoRD & 0.245 & 0.825 & & & & & & & & & & & \\
\hline DRD & 0.190 & 0.681 & 0.740 & & & & & & & & & & \\
\hline
\end{tabular}


Table 2. Cont.

\begin{tabular}{|c|c|c|c|c|c|c|c|c|c|c|c|c|c|}
\hline & POS & CRD & CoRD & DRD & ERD & ExRD & LRD & LSE & MRD & ORD & PIS & PMS & PRD \\
\hline ERD & 0.126 & 0.670 & 0.702 & 0.459 & & & & & & & & & \\
\hline ExRD & 0.142 & 0.616 & 0.711 & 0.683 & 0.755 & & & & & & & & \\
\hline LRD & 0.334 & 0.712 & 0.799 & 0.537 & 0.532 & 0.481 & & & & & & & \\
\hline LSE & 0.248 & 0.080 & 0.142 & 0.097 & 0.044 & 0.105 & 0.109 & & & & & & \\
\hline MRD & 0.192 & 0.798 & 0.855 & 0.740 & 0.710 & 0.681 & 0.882 & 0.148 & & & & & \\
\hline ORD & 0.166 & 0.732 & 0.793 & 0.680 & 0.754 & 0.701 & 0.627 & 0.056 & 0.764 & & & & \\
\hline PIS & 0.868 & 0.173 & 0.164 & 0.131 & 0.091 & 0.085 & 0.247 & 0.175 & 0.110 & 0.080 & & & \\
\hline PMS & 0.855 & 0.213 & 0.222 & 0.133 & 0.134 & 0.150 & 0.262 & 0.119 & 0.158 & 0.200 & 0.748 & & \\
\hline PRD & 0.150 & 0.723 & 0.803 & 0.731 & 0.736 & 0.830 & 0.583 & 0.102 & 0.798 & 0.786 & 0.127 & 0.138 & \\
\hline
\end{tabular}

Notes: POS—project ownership success; CRD—consultant-related delay; CoRD—contractor-related delay; DRD—design-related delay; ERD—equipment-related delay; ExRD—external-related delay; LRD—labor-related delay; LSE-leadership self-efficacy; MRD—material-related delay; ORD—owner-related delay; PIS—project investment success; PMS — project management success; PRD—project-related delay.

Table 3. Assessments of formative dimensions of CDFs and TMCP Success $(\mathrm{N}=211)$.

\begin{tabular}{|c|c|c|c|c|}
\hline $\begin{array}{c}\text { Second Order } \\
\text { (Formative) Construct }\end{array}$ & First-Order (Reflective) Construct & Path Coefficient & $t$-Value & VIF \\
\hline \multirow[t]{3}{*}{ TMCP Success } & Project Management Success & $0.466^{* *}$ & 22.455 & 2.178 \\
\hline & Project Investment Success & $0.327^{* *}$ & 20.384 & 2.123 \\
\hline & Project Ownership Success & $0.333^{* *}$ & 24.259 & 2.692 \\
\hline \multirow[t]{9}{*}{ Critical Delay Factors } & Project-Related Delay & $0.134^{* *}$ & 16.920 & 3.031 \\
\hline & Owner-Related Delay & $0.139 * *$ & 17.517 & 2.616 \\
\hline & Design-Related Delay & $0.081^{* *}$ & 15.969 & 2.558 \\
\hline & Consultant-Related Delay & $0.166^{* *}$ & 22.047 & 3.742 \\
\hline & Contractor-Related Delay & $0.175^{* *}$ & 21.602 & 4.822 \\
\hline & Labor-Related Delay & $0.117^{* *}$ & 18.277 & 3.212 \\
\hline & Material-Related Delay & $0.132 * *$ & 18.135 & 4.433 \\
\hline & Equipment-Related Delay & $0.129 * *$ & 13.448 & 2.785 \\
\hline & External-Related Delay & $0.132^{* *}$ & 14.815 & 2.751 \\
\hline
\end{tabular}

Notes: ** represents $p<0.01$.

\subsection{Structural Equation Model}

The PLS-SEM bootstrap approach was applied to analyze the structural model of TMCP success and its relationship with other latent constructs, i.e., CDFs and LSE [71]. The assessment outcome of formative dimensions of CDFs and TMCP success is presented in Table 3 and Figure 2 [73]. The structural model of TMCP success with dimensions can be visualized in Figure 2. The structure model assessments presented the path coefficients and $t$-values of the predictors of TMCP success. The results shown in Table 4 revealed a significantly negative effect of CDFs on TMCP success, that is, $\beta=-2.88, t$-value $=5.73$, and $p<0.01$-hence, supporting the first hypothesis of the study. The results show that a $1 \%$ increase in delays due to the occurrence of CDFs could cause a $28.8 \%$ negative change in TMCP success. The results in Table 4 also revealed a significant and direct effect of LSE on TMCP success, i.e., $\beta=0.184, t$-value $=3.143, p<0.01$. The impact of leadership self-efficacy on TMCP success indicated a $1 \%$ increase in LSE, resulting in a $18.4 \%$ positive change in TMCP success. Moreover, the analysis of the data supports the second hypothesis, which assumes the moderating role of LSE in the direct consequence of CDFs on TMCP success. The moderating effect of LSE is exhibited in Figure 3. In Table 5, note that $\beta=0.103, t$-values $=2.316$, and $p<0.05$, indicating that high LSE positively and significantly moderate the CDF effects on TMCP success. 


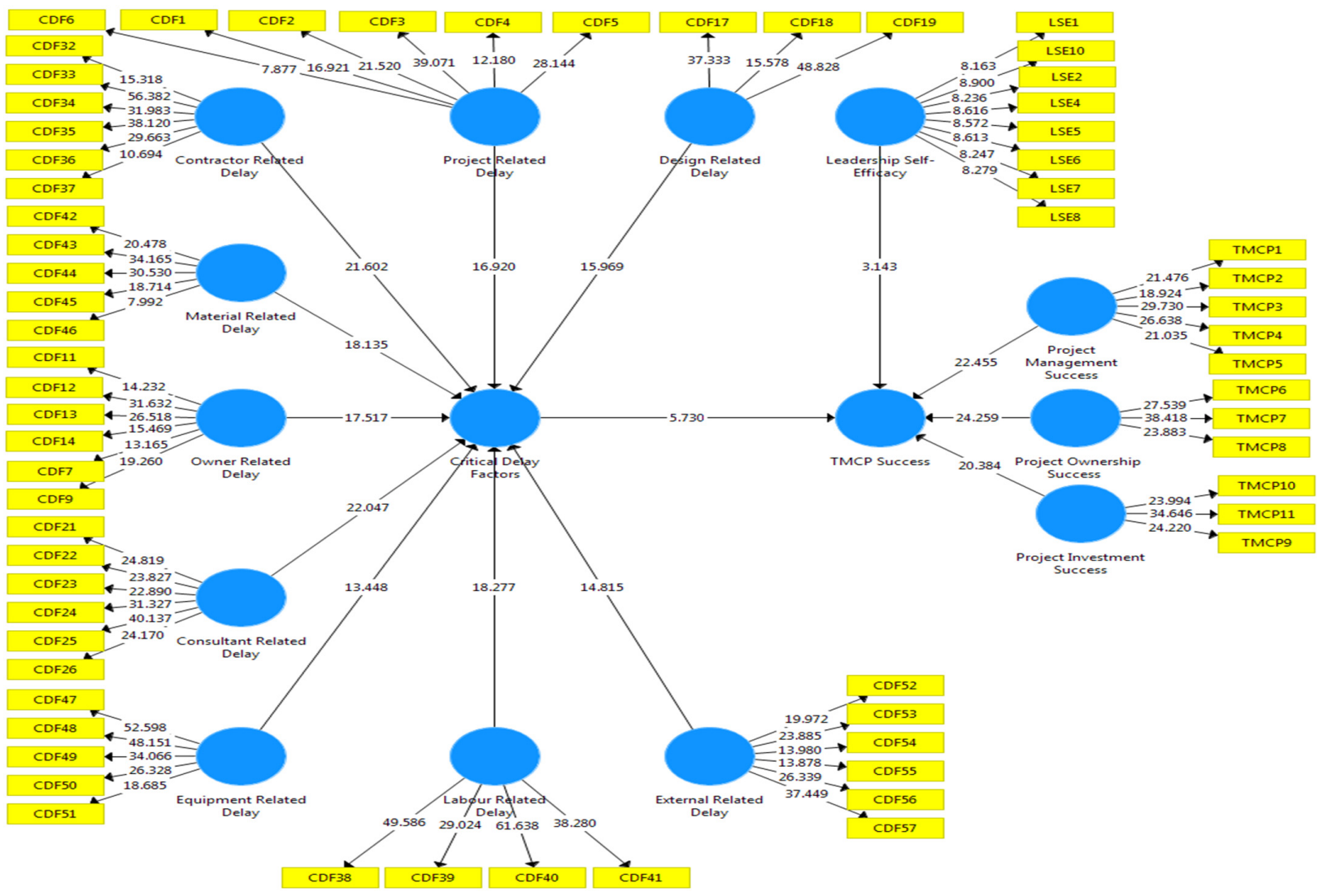

Figure 2. Structural model of TMCP success.

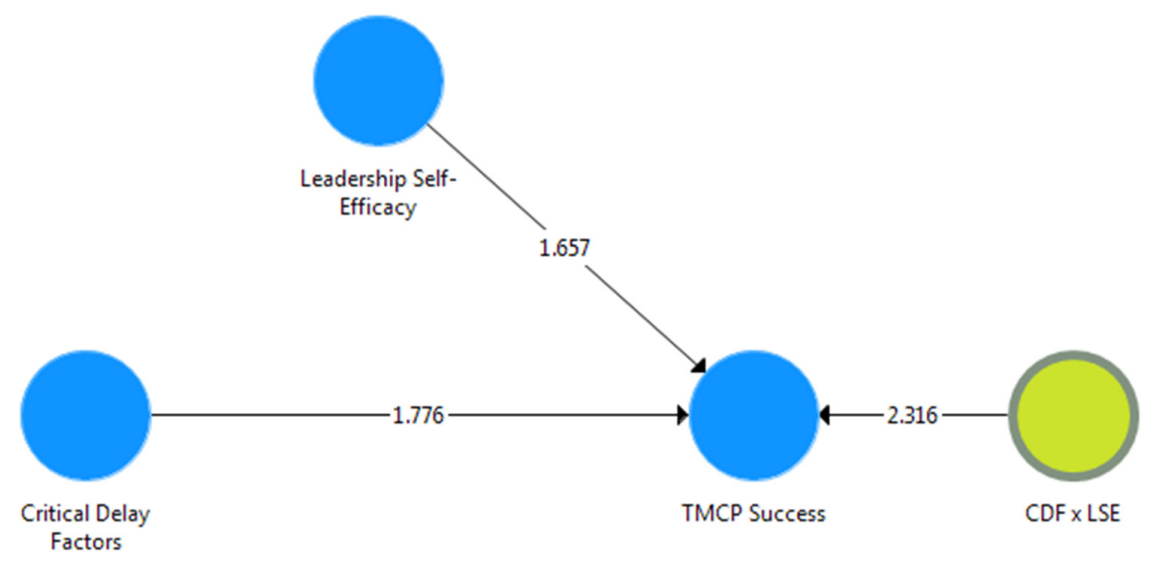

Figure 3. Leadership Self-efficacy as a Moderator.

Table 4. Direct relationships $(\mathrm{N}=211)$.

\begin{tabular}{ccccccc}
\hline & $\boldsymbol{\beta}$ & $\boldsymbol{t}$-Value & $\mathbf{f}^{\mathbf{2}}$ & $\mathbf{R}^{\mathbf{2}}$ & $\mathbf{Q}^{\mathbf{2}}$ & $\mathbf{S R M R}$ \\
\hline Critical Delay Factors -> TMCP Success & $-0.288^{* *}$ & 5.730 & 0.146 & 0.124 & 0.152 & 0.073 \\
Leadership Self-Efficacy -> TMCP Success & $0.184^{* *}$ & 3.143 & 0.164 & & & \\
\hline
\end{tabular}

Notes: ${ }^{* *}$ represent $p<0.01$.

Table 5. Moderating effect of LSE $(\mathrm{N}=211)$.

\begin{tabular}{cccccc}
\hline & $\boldsymbol{\beta}$ & $\boldsymbol{t}$-Value & $p$-Value & $\mathbf{f}^{2}$ & $\mathbf{R}^{\mathbf{2}}$ \\
\hline CDF x LSE -> TMCP Success & $0.103^{*}$ & 2.316 & 0.010 & 0.062 & 0.152 \\
\hline
\end{tabular}


In addition, the variance determinant R2 (0.124) in Table 4 shows that predictor variable CDFs explained $12.4 \%$ of the variance in TMCP success, whereas $15.2 \%$ of TMCP success variance was explained by predictor variables CDFs with LSE moderation. The change in $\mathrm{R}^{2}$ from 0.124 to 0.152 indicates an improvement in the variance explained in TMCP success after LSE's moderating role. The results also show Cohen's effect size as f2-value [74] in Table 4, which is 0.146 (smaller) and 0.164 (medium) for the effects of CDFs and LSE on TMCP success, respectively [75]. The effect size of CDFs is relatively smaller than that of LSE's. Lastly, the results in Table 4 present the standardized root mean square residual (SRMR) value $=0.073$, which is lower than the standard maximum threshold (0.08), indicating the goodness of fit [72,76]. As shown in Table 4, the Stone-Geisser Q2 value for TMCP success is 0.152 . As this value is greater than zero, it confirms the structural model's credibility and relevance [65].

\section{Discussion}

The present study conceptualized a model linking critical delay factors (CDFs), leadership self-efficacy (LSE), and transnational mega construction project (TMCP) success based on theoretical insights from previous research. The direct relationship between CDFs and TMCP success was conceptualized as Hypothesis 1; whereas, Hypothesis 2 theorized the moderating influence of LSE on the relationship between CDFs and TMCP success. Drawing on study data $(\mathrm{N}=211)$ extracted from the $\mathrm{CPEC}$, the formulated hypotheses were empirically tested with PLS-SEM. The present study found new evidence supporting the negative effects of CDFs on TMCP success, wherein LSE positively moderated this relationship. In practice, there has been an undeniable relationship between stakeholder performance and project success. This relationship has helped the authors concur with the presumption that stakeholders can influence the projects' outcome-be it the owner, the contractor, or the project leader. The results indicate that critical delay factors (CDFs) have a significant negative relationship on transnational mega construction project (TMCP) success, which lends empirical support to the views of other studies that have suggested that CDFs impact negatively the success of projects $[16,63,77]$. CDFs were found to have a significant and negative effect on all three dimensions of TMCP success, namely project management success (PMS), project ownership success (POS), and project investment success (PIS), which corroborates the findings of Zwikael and Meredith [16]. For this study, a $1 \%$ increase in delays due to CDFs was found to cause a $28.8 \%$ negative change in TMCP success.

Interestingly, it was found that predictor variable (i.e., $\mathrm{CDFs}$ ) explained $12.4 \%$ of the variance in TMCP success. With LSE moderation, the predictor variable CDFs explained $15.2 \%$ of the variance in TMCP success. This shows the importance of the moderating role of LSE and the effect of the leadership aspect on project success. Furthermore, the results empirically support and contribute to the growing discussion that LSE is necessary to realize project success and the multidimensional success of projects. These results suggest that LSE is a vital component for project management $[42,48,78]$ and organizations should identify leaders with high self-efficacy. These leaders can address obstacles, initiate change, and be the drivers of success. Hence, it is concluded that LSE enables success through effective networks [2], which in turn may have an effect on lessening project delays.

It was found that the direct effect of CDFs is stronger on project success than LSE, which may suggest that existing project obstacles affect megaproject success directly in multiple dimensions. On the other side, LSE may also impact megaproject success directly in addition to its moderating role. This evidence corroborates with the findings of Pillai and Williams [39] and Seibert et al. [58], which conclude that LSE impacts organizational- and team-related outcomes indirectly (i.e., mediating relationships). Success factors are diverse, so it is convenient to determine the real causes and effects of success for each stakeholder and context. Success is influenced by CDFs and LSE. In the case of CDFs, these may have a long-term influence and broader context (act across multiple phases) on projects, which explains the direct effect. For the LSE case, the performance of stakeholders (and leaders) 
is one critical success factor that cannot be ignored. The role of leaders determines the individuals' performance and-through motivation and encouragement-the performance of co-workers and/or subordinates, which explains the indirect effect. Last but not least, the present study provided empirical evidence in favor of the moderating role of LSE on the relationship between CDFs and TMCP success. Earlier studies in project management literature have also focused on uncovering the influential role of self-efficacy in project teams and leadership [79-82]. Blomquist et al. [44] highlighted that self-efficacy of the project management team has a significant positive effect on project performance, hence it can be regarded as a significant predictor of megaproject success. Din [80] also revealed evidence on the moderating influence of self-efficacy on project success. Hence, the present study's finding on the moderating influence of LSE in TMCP success also validates the conclusions drawn by Blomquist et al. [44] and Din [80].

\subsection{Theoretical Implications}

This study contributes to the literature of the construction industry and project management in many significant ways. Prior research on transnational megaproject success dimensions typically depicted the causes and effects of projects' overall success, with very few studies seeking to reveal the depth of any further project success multidimensions [62]. The authors of the study considered major critical delay factors affecting a megaproject's success and studied their impact on multiple facets of success. The first theoretical contribution of this study is that it proved the notion that CDFs have a huge role in project success and failure and used leadership traits as an impactful tool to moderate the said relationship. The effect of CDFs on project success was empirically proven with elaborated possible delay factors. The study included each factor and analyzed the LSE's moderating role in the negative relationship between CDFs and megaproject success. The direct relationship of project constructs in the results also reveals a 3\% difference between variance in success explained by CDFs alone and CDFs with LSE. The LSE was a statistically proven moderator of TMCP success in the owner, investment, and project management contexts. The self-efficacy of a leader and its revelation as a powerful trait of an individual in view of project success is an interesting contribution of this study.

The second significant contribution of the study is its consideration of multiple success dynamics in addition to the CDFs. The study extends the dimensions of success in megaprojects to project management performance, project ownership behaviors, and project investment dynamics. This is an extension and continuation of the study by Zwikael and Meredith [16]. The role of CDFs on multiple success dimensions was studied, which is novel in the literature. This study shows that success factors are diverse and totally contextual, making it convenient to determine the real causes and their effect on project success. The study results are in line with Pillai and Williams [39] and Seibert et al. [58], which conclude that LSE impacts organizational and product success indirectly. Considering these PLS-SEM-based estimations, the findings provide a more refined LSE interpretation and its effects on TMCP success, enhancing the existing literature regarding construction megaproject success.

\subsection{Managerial Implications}

Apart from the theoretical contributions, this study offers some practical implications that can be applied to achieve TMCP success. The study provided evidence of how LSEs significantly moderate TMCP success and CDFs. Therefore, the leaders of a project should put self-efficacy into effect as a key leadership trait. The recruitment process in organizations can be conducted while being mindful of the LSE of the candidates to ensure the projects' ultimate success [83]. Training programs can be introduced to instruct LSE as a tool to achieve a projects' objectives. Besides training leaders to maximize LSE, the construction industry and other manufacturing industries can hire CEOs and managers with high LSE [84]. Prioritizing LSE in recruitment criteria might reflect the same attributes in the team, leading to an increased possibility of project success. The study's result 
provided a perspective of leadership behavior tendencies in terms of LSE, which can be manipulated for achieving better interests for organizations in the future. The findings might also offer global project managers and organizations insight into a rather overlooked aspect of success, i.e., leadership behavior.

Similarly, the identification of the linkages between CDFs and TMCP success can be practically utilized by increasing awareness and willingness to react proactively towards any foreseen delays in megaprojects. Importantly, to ensure that megaproject's planning and execution are not adversely hit by any delay factors (at initial or even later stages), megaproject teams can conduct preliminary assessments to identify potential delay factors and appropriately formulate mitigating strategies [32]. Experience gained from similar and/or earlier megaprojects can offer strategic insights in managing CDFs through timely interventions to minimize the adverse impact of these delays. Identification of the most critical delay factors would allow the megaproject teams (as directed by their self-efficacious leaders) to avoid any serious threats to the megaproject [85]. Lastly, by highlighting the negative effects of CDFs on TMCP success, this study provides an opportunity for project leaders and managers to leverage success in megaprojects through greater preparedness during various stages of the project lifecycle. Proactive interventions can ultimately aid megaprojects to achieve their projected goals within schedule and budget despite the occurrence of unexpected and/or unavoidable delays [32,85].

\subsection{Limitations and Future Work}

Among the limitations and shortcomings of this study, the first noticeable factor is that this study is limited to the CPEC project. This limitation can inspire practitioners to further study the theory on rather diverse projects from within or without the construction industry. Future studies should investigate the interaction of constructs used in this study with a broader perspective to explore the insight in multiple industries as well. The same research design could be applied to test the role of LSE in other organizations and settings. The link between LSE and effective leadership should be explored in the same set of variables. Another limitation of the study involves using cross-sectional survey as a tool to collect data for the study. This research design might have affected the possibility of achieving an in-depth analysis of the role of LSE on the relationship of CDFs and TMCP success, since the cross-sectional design may fail to estimate the desired causal inferences [86]. Therefore, future studies could consider other data collection techniques, such as the longitudinal data collection method, to extend the results and comparisons through empirical investigations. Other data collection mechanics could also be used to reflect better results. In addition to the suggestions above, it is recommended to address the one-to-one relationship of project CDFs and success elements for a holistic insight into the interrelation between study constructs. Due to the limited accessibility to the Chinese operatives in Pakistan (e.g., security protocols and confidentiality) associated with the CPEC megaproject, future studies may consider exploring research initiatives that can also engage Chinese officials to gain deeper insights on CDFs, LSE, and TMCP success in the China-Pakistan Economic Corridor. Lastly, the present study adapted the multidimensional scale of project success published in seminal research by U1-Musawir et al. [62]. Subsequently, leading international journals (e.g., Engineering Construction and Architectural Management, Project Management Journal, International Journal of Managing Projects in Business, and the International Journal of Project Management) have continued to publish mounting evidence on project success [19,86-92]. However, there is still limited evidence on the performance of these projects at various stages of the project lifecycle. Hence, future studies should expand their research focus by involving project performance as a critical milestone towards project success [43,90-94].

\section{Conclusions}

This paper emphasizes the importance of high LSE and its positive impact on the relationship between CDFs and transnational megaproject success. The paper's findings pointed out the adverse effects of delay factors on the success of megaprojects. LSE's role 
in transnational megaproject success has provided insight into leaders' behavioral aspects and their impact on the overall megaproject outcomes, especially when constrained by multiple delay factors. The study's transnational context highlighted the major threatening challenges for megaproject success distinctively, for instance, project finances, project ownership, and project management. Transnational projects are complex in nature due to the cultural, social, and economic differences of team members. The nature of such projects oftentimes is virtual, but it is somehow not the case with construction projects. For construction projects, teams are globally located, employ a broad professional spectrum, and remain virtually connected at times. The spirit and self-confidence of leadership from individual leaders passed on to the subordinates can work wonders on behaviors, leading to the successful completion of these types of highly demanding and challenging megaprojects. The timeframe of megaprojects cannot be ignored whenever the success is determined; thus, any delays can hugely affect the megaprojects' success, as empirically evidenced in this research.

Author Contributions: Conceptualization, U.Z. and L.F.-P.; methodology, U.Z. and S.N.; software, S.N.; validation, S.N.; formal analysis, S.N.; investigation, U.Z., S.A., and S.N.; resources, U.Z., S.A. and S.N.; data curation, U.Z. and S.N.; writing — original draft preparation, U.Z., L.F.P., S.A., P.F. and S.N.; writing - review and editing, U.Z., S.A., L.F.-P., P.F. and M.P.; visualization, S.N.; supervision, U.Z. and L.F.-P.; project administration, U.Z. All authors have read and agreed to the published version of the manuscript.

Funding: This research received no external funding.

Informed Consent Statement: Informed consent was initially obtained from all participants who had volunteered to participate in this study.

Data Availability Statement: The study data is available on request from the corresponding author.

Conflicts of Interest: The authors declare no conflict of interest.

\section{References}

1. Li, Y.; Lu, Y.; Taylor, J.E.; Han, Y. Bibliographic and comparative analyses to explore emerging classic texts in megaproject management. Int. J. Proj. Manag. 2018, 36, 342-361. [CrossRef]

2. Schweiger, D.M.; Atamer, T.; Calori, R. Transnational project teams and networks: Making the multinational organization more effective. J. World Bus. 2003, 38, 127-140. [CrossRef]

3. Altshuler, A.; Luberoff, D. Mega-Projects: The Changing Politics of Urban Public Investment; Brookings Institution Press: Washington, DC, USA, 2004; p. 20433.

4. Eden, D.; Zuk, Y. Seasickness as a Self-Fulfilling Prophecy: Raising Self-Efficacy to Boost Performance at Sea. J. Appl. Psychol. 1995, 80, 628-635. [CrossRef]

5. Burns, D.A. Leader Development or Leader Distress? Examining the Interactive Effects of Leadership Self-Efficacy and Situational Strength on Perceptions of Stress. Perform. Physiol. Responses 2016, 11, 125.

6. Assaf, S.A.; Al-Heji, S. Causes of delay in large construction projects. Int. J. Proj. Manag. 2006, 24, 349-357. [CrossRef]

7. Carvalho, M.M.; Rabechini, R. Can project sustainability management impact project success? An empirical study applying a contingent approach. Int. J. Proj. Manag. 2017, 35, 1120-1132. [CrossRef]

8. Ika, L.A. Project Success as a Topic in Project Management Journals. Proj. Manag. J. 2009, 39, 28-42. [CrossRef]

9. Radujković, M.; Sjekavica, M. Project Management Success Factors. Procedia Eng. 2017, 196, 607-615. [CrossRef]

10. Zwikael, O.; Smyrk, J. A general framework for gauging the performance of initiatives to enhance organizational value. Br. J. Manag. 2012, 23, S6-S22. [CrossRef]

11. Kardes, I.; Ozturk, A.; Cavusgil, S.T.; Cavusgil, E. Managing global megaprojects: Complexity and risk management. Int. Bus. Rev. 2013, 22, 905-917. [CrossRef]

12. Flyvbjerg, B.; Bruzelius, N.; Rothengatter, W. Megaprojects and Risk: An Anatomy of Ambition; Cambridge University Press: Cambridge, MA, USA, 2003.

13. He, Q.; Luo, L.; Hu, Y.; Chan, A.P.C. Measuring the complexity of mega construction projects in China-A fuzzy analytic network process analysis. Int. J. Proj. Manag. 2015, 33, 549-563. [CrossRef]

14. Jaafari, A. Construction management know-how for transnational projects. Int. J. Proj. Manag. 1984, 2, 198-206. [CrossRef]

15. Wu, G.; Zhao, X.; Zuo, J.; Zillante, G. Effects of contractual flexibility on conflict and project success in megaprojects. Int. J. Confl. Manag. 2018, 29, 253-278. [CrossRef]

16. Zwikael, O.; Meredith, J. Evaluating the Success of a Project and the Performance of Its Leaders. IEEE Trans. Eng. Manag. 2021, 68, 1745-1757. [CrossRef] 
17. Li, H.; Guo, H.L. International Journal of Project Management special issue on "Complexities in managing mega construction projects". Int. J. Proj. Manag. 2011, 29, 795-796. [CrossRef]

18. Grisham, T.W. International Project Management: Leadership in Complex Environments; John Wiley \& Sons, Inc.: Hoboken, NJ, USA, 2009.

19. Zaman, U.; Nadeem, R.D.; Nawaz, S. Examining the effect of xenophobia on "transnational" mega construction project (MCP) success: Moderating role of transformational leadership and high-performance work (HPW) practices. Eng. Constr. Archit. Manag. 2020, 27, 1119-1143. [CrossRef]

20. Alaghbari, W.; Kadir, M.R.A.; Salim, A.; Ernawati. The significant factors causing delay of building construction projects in Malaysia. Eng. Constr. Archit. Manag. 2007, 14, 192-206. [CrossRef]

21. Sambasivan, M.; Soon, Y.W. Causes and effects of delays in Malaysian construction industry. Int. J. Proj. Manag. 2007, 25, 517-526. [CrossRef]

22. Ansah, R.H.; Sorooshian, S. 4P delays in project management. Eng. Constr. Archit. Manag. 2018, 25, 62-76. [CrossRef]

23. Birgonul, M.T.; Dikmen, I.; Bektas, S. Integrated Approach to Overcome Shortcomings in Current Delay Analysis Practices. J. Constr. Eng. Manag. 2015, 141, 04014088. [CrossRef]

24. Durdyev, S.; Hosseini, M.R. Causes of delays on construction projects: A comprehensive list. Int. J. Manag. Proj. Bus. 2019, 13, 20-46. [CrossRef]

25. Banobi, E.T.; Jung, W. Causes and mitigation strategies of delay in power construction projects: Gaps between owners and contractors in successful and unsuccessful projects. Sustainability 2019, 11, 5973. [CrossRef]

26. Batool, A.; Abbas, F. Reasons for delay in selected hydro-power projects in Khyber Pakhtunkhwa (KPK), Pakistan. Renew. Sustain. Energy Rev. 2017, 73, 196-204. [CrossRef]

27. Derakhshanalavijeh, R.; Teixeira, J.M.C. Cost overrun in construction projects in developing countries, Gas-Oil industry of Iran as a case study. J. Civ. Eng. Manag. 2017, 23, 125-136. [CrossRef]

28. Bajjou, M.S.; Chafi, A. Empirical study of schedule delay in Moroccan construction projects. Int. J. Constr. Manag. 2020, 20, 783-800. [CrossRef]

29. Enshassi, A.; Al Najjar, J.; Kumaraswamy, M. Delays and cost overruns in the construction projects in the Gaza Strip. J. Financ. Manag. Prop. Constr. 2009, 14, 126-151. [CrossRef]

30. Sepasgozar, S.M.E.; Karimi, R.; Shirowzhan, S.; Mojtahedi, M.; Ebrahimzadeh, S.; McCarthy, D. Delay Causes and Emerging Digital Tools: A Novel Model of Delay Analysis, Including Integrated Project Delivery and PMBOK. Buildings 2019,9 , 191.

31. Al-Momani, A.H. Construction delay: A quantitative analysis. Int. J. Proj. Manag. 2000, 18, 51-59. [CrossRef]

32. Yap, J.B.H.; Goay, P.L.; Woon, Y.B.; Skitmore, M. Revisiting critical delay factors for construction: Analysing projects in Malaysia. Alexandria Eng. J. 2021, 60, 1717-1729. [CrossRef]

33. Yukl, G.; Gardner, W.L.; Uppal, N. Leadership in Organizations, 9th ed.; Pearson: Noida, India, 1981.

34. Bandura, A. Self-efficacy: Toward a unifying theory of behavioral change. Psychol. Rev. 1977, 84, 191-215. [CrossRef]

35. Yukl, G.A.; Becker, W.S. Effective Empowerment in Organizations. Organ. Manag. J. 2006, 3, 210-231. [CrossRef]

36. Northouse, P.G. Introduction To Leadership: Concepts And Practice Free Collection, 4th ed.; SAGE Publishing: Los Angeles, CA, USA, 2014; ISBN 9781452259666.

37. Adewale, A.S.; Ghavifekr, S. Leadership self-efficacy and staff organizational citizenship behavior in higher education institutions: Experience from Nigeria. Int. J. Leadersh. Educ. 2019, 22, 116-133. [CrossRef]

38. Hoyt, C.L.; Blascovich, J. The role of leadership self-efficacy and stereotype activation on cardiovascular, behavioral and self-report responses in the leadership domain. Leadersh. Q. 2010, 21, 89-103. [CrossRef]

39. Pillai, R.; Williams, E.A. Transformational leadership, self-efficacy, group cohesiveness, commitment, and performance. J. Organ. Chang. Manag. 2004, 17, 144-159. [CrossRef]

40. Gist, M.E.; Mitchell, T.R. Self-Efficacy: A Theoretical Analysis of Its Determinants and Malleability. Acad. Manag. Rev. 1992, 17, 183-211. [CrossRef]

41. Redmond, M.R.; Mumford, M.D.; Teach, R. Putting creativity to work: Effects of leader behavior on subordinate 805 creativity. Organ. Behav. Hum. Decis. Process. 1993, 55, 120-151. [CrossRef]

42. Paglis, L.L.; Green, S.G. Leadership self-efficacy and managers' motivation for leading change. J. Organ. Behav. 2002, 23, 215-235. [CrossRef]

43. Zaman, U.; Florez-Perez, L.; Khwaja, M.G.; Abbasi, S.; Qureshi, M.G. Exploring the critical nexus between authoritarian leadership, project team member's silence and multi-dimensional success in a state-owned mega construction project. Int. J. Proj. Manag. 2021, 39, 873-886. [CrossRef]

44. Blomquist, T.; Dehghanpour, A.; Thomas, J. Project management self-efficacy as a predictor of project performance: Constructing and validating a domain-specific scale. Int. J. Proj. Manag. 2016, 34, 1417-1432. [CrossRef]

45. Chen, G.; Gully, S.M.; Eden, D. General self-efficacy and self-esteem: Toward theoretical and empirical distinction between correlated self-evaluations. J. Organ. Behav. 2004, 25, 375-395. [CrossRef]

46. Fitzgerald, S.; Schutte, N.S. Increasing transformational leadership through enhancing self-efficacy. J. Manag. Dev. 2010, 29, 495-505. [CrossRef]

47. Ali, H.E.; Schalk, R.; van Engen, M.; van Assen, M. Leadership Self-Efficacy and Effectiveness: The Moderating Influence of Task Complexity. J. Leadersh. Stud. 2018, 11, 21-40. [CrossRef] 
48. Ng, K.Y.; Ang, S.; Chan, K.Y. Personality and Leader Effectiveness: A Moderated Mediation Model of Leadership Self-Efficacy, Job Demands, and Job Autonomy. J. Appl. Psychol. 2008, 93, 733-743. [CrossRef] [PubMed]

49. Arditi, D.; Nayak, S.; Damci, A. Effect of organizational culture on delay in construction. Int. J. Proj. Manag. 2017, 35, 136-147. [CrossRef]

50. Adewale, A.S.; Jamil, H.; Khadijah, A.S. Leadership self-efficacy, change oriented behavior and organizational citizenship behavior: The moderating effect of experience. Int. J. High. Educ. 2019, 8, 36-51. [CrossRef]

51. Ladegard, G.; Gjerde, S. Leadership coaching, leader role-efficacy, and trust in subordinates. A mixed methods study assessing leadership coaching as a leadership development tool. Leadersh. Q. 2014, 25, 631-646. [CrossRef]

52. Shrivastva, A.; Gupta, P.S.; Patle, P.M. Comparative Analysis of Two Projects for Identifying the Factors Responsible for Timely. Int. J. Eng. Res. Curr. Trends 2021, 3, 84-86.

53. Elbeltagi, E.; Ammar, M.; Sanad, H.; Kassab, M. Overall multiobjective optimization of construction projects scheduling using particle swarm. Eng. Constr. Archit. Manag. 2016, 23, 113. [CrossRef]

54. Jahangoshai Rezaee, M.; Yousefi, S.; Chakrabortty, R.K. Analysing causal relationships between delay factors in construction projects: A case study of Iran. Int. J. Manag. Proj. Bus. 2021, 14, 412-444. [CrossRef]

55. Ren, S.; Chadee, D. Ethical leadership, self-efficacy and job satisfaction in China: The moderating role of guanxi. Pers. Rev. 2017, 46, 371-388. [CrossRef]

56. Luthans, F.; Peterson, S.J. Employee engagement and manager self-efficacy: Implications for managerial effectiveness and development. J. Manag. Dev. 2002, 21, 376-387. [CrossRef]

57. Hannah, S.T.; Luthans, F. A Cognitive Affective Processing Explanation of Positive Leadership. In Affect and Emotion: New Directions in Management Theory and Research; Information Age Publishing Inc.: Charlotte, NC, USA, 2008; pp. 97-136.

58. Seibert, S.E.; Sargent, L.D.; Kraimer, M.L.; Kiazad, K. Linking Developmental Experiences to Leader Effectiveness and Promotability: The Mediating Role of Leadership Self-Efficacy and Mentor Network. Pers. Psychol. 2017, 70, 357-397. [CrossRef]

59. Joslin, R.; Müller, R. The impact of project methodologies on project success in different project environments. Int. J. Manag. Proj. Bus. 2016, 9, 364-388. [CrossRef]

60. Gondia, A.; Siam, A.; El-Dakhakhni, W.; Nassar, A.H. Machine Learning Algorithms for Construction Projects Delay Risk Prediction. J. Constr. Eng. Manag. 2020, 146, 04019085. [CrossRef]

61. Chemers, M.M.; Hu, L.T.; Garcia, B.F. Academic self-efficacy and first-year college student performance and adjustment. J. Educ. Psychol. 2001, 93, 55-64. [CrossRef]

62. Musawir, A.; Serra, C.E.M.; Zwikael, O.; Ali, I. Project governance, benefit management, and project success: Towards a framework for supporting organizational strategy implementation. Int. J. Proj. Manag. 2017, 35, 1658-1672. [CrossRef]

63. Ahmadabadi, A.A.; Heravi, G. The effect of critical success factors on project success in Public-Private Partnership projects: A case study of highway projects in Iran. Transp. Policy 2019, 73, 152-161. [CrossRef]

64. Akter, S.; Fosso Wamba, S.; Dewan, S. Why PLS-SEM is suitable for complex modelling? An empirical illustration in big data analytics quality. Prod. Plan. Control 2017, 28, 1011-1021. [CrossRef]

65. Hair, J.F.; Hult, G.T.M.; Ringle, C.M.; Sarstedt, M. A Primer on Partial Least Squares Structural Equation Modeling (PLS-SEM), 2nd ed.; Sage Publications, Inc.: Thousand Oaks, CA, USA, 2017.

66. Fuller, C.M.; Simmering, M.J.; Atnic, G.; Atnic, Y.; Babin, B.J. Common methods variance detection in business research. J. Bus. Res. 2016, 69, 3192-3198. [CrossRef]

67. Podsakoff, P.M.; Mackenzie, S.B.; Lee, J.; Podsakoff, N.P. Common Method Biases in Behavioral Research: A Critical Review of the Literature and Recommended Remedies. J. Appl. Psychol. 2003, 88, 879-903. [CrossRef]

68. Cronbach, L.J. Coefficient alpha and the internal structure of tests. Psychometrika 1951, 16, 297-334. [CrossRef]

69. Hair, J.F.; Sarstedt, M.; Hopkins, L.; Kuppelwieser, V.G. Partial Least Squares Structural Equation Modeling ( PLS-SEM ): An Emerging Tool in Business Research. Eur. Bus. Rev. 2014, 26, 106-121. [CrossRef]

70. Manley, S.C.; Jr, J.F.H.; Jr, R.I.W.; Mcdowell, W.C. Essential new PLS-SEM analysis methods for your entrepreneurship analytical toolbox. Int. Entrep. Manag. J. 2020, 11, 1452. [CrossRef]

71. Hair, J.F.; Ringle, C.M.; Sarstedt, M. PLS-SEM: Indeed a silver bullet. J. Mark. Theory Pract. 2011, 19, 139-152. [CrossRef]

72. Henseler, J.; Ringle, C.M.; Sarstedt, M. A new criterion for assessing discriminant validity in variance-based structural equation modeling. J. Acad. Mark. Sci. 2015, 43, 115-135. [CrossRef]

73. Tehseen, S.; Sajilan, S.; Gadar, K.; Ramayah, T. Assessing cultural orientation as a reflective-formative second order constructA recent PLS-SEM approach. Rev. Integr. Bus. Econ. Res. 2017, 6, 38.

74. Cohen, J. Statistical Power Analysis for the Behavioral Sciences; Academic Press, Inc.: Cambridge, MA, USA, 2013.

75. Selya, A.S.; Rose, J.S.; Dierker, L.C.; Hedeker, D.; Mermelstein, R.J. A practical guide to calculating Cohen's f 2, a measure of local effect size, from PROC MIXED. Front. Psychol. 2012, 3, 1-6. [CrossRef]

76. Tenenhaus, M.; Amato, S.; Vinzi, E.V. A global goodness-of-fit index for PLS structural equation modelling. XLII SIS Sci. Meet. 2004, 1, 739-742.

77. Aibinu, A.A.; Jagboro, G.O. The effects of construction delays on project delivery in Nigerian construction industry. Int. J. Proj. Manag. 2002, 20, 593-599. [CrossRef]

78. Anderson, D.W.; Krajewski, H.T.; Goffin, R.D.; Jackson, D.N. A leadership self-efficacy taxonomy and its relation to effective leadership. Leadersh. Q. 2008, 19, 595-608. [CrossRef] 
79. Schaffer, S.P.; Chen, X.; Zhu, X.; Oakes, W.C. Self-efficacy for cross-disciplinary learning in project-based teams. Eng. Educ. 2012, 101, 82-94. [CrossRef]

80. Din, A.N.U. Impact of Emotional Intelligence on Project Success with Mediation of Team Cohesion and Moderation of Self-Efficacy; Capital University of Science and Technology: Islamabad, Pakistan, 2017.

81. Hassan, M.M.; Bashir, S.; Abbas, S.M. The Impact of Project Managers' Personality on Project Success in NGOs: The Mediating Role of Transformational Leadership. Proj. Manag. J. 2017, 74-87. [CrossRef]

82. Lemboye, O.T. Walden University; Walden University: Minneapolis, MN, USA.

83. Carleton, E.L.; Barling, J.; Trivisonno, M. Leaders' trait mindfulness and transformational leadership: The mediating roles of leaders' positive affect and leadership self-efficacy. Can. J. Behav. Sci. 2018, 50, 185-194. [CrossRef]

84. Shamroukh, S.S. The Impact of IT Project Management Tools and Leadership Self-Efficacy on Project Success; University of Bolton: Bolton, UK, 2019.

85. Abdulla Alsulaiti, A.; Kerbache, L. Analysis of Critical Delay Factors in Construction Projects with a Focus on Qatar. Int. J. Bus. Econ. Res. 2020, 9, 130. [CrossRef]

86. Rindfleisch, A.; Malter, A.J.; Ganesan, S.; Moorman, C. Cross-Sectional Versus Longitudinal Survey Research: Concepts, Findings, and Guidelines. J. Mark. Res. 2008, 45, 261-279. [CrossRef]

87. Gemino, A.; Horner Reich, B.; Serrador, P.M. Agile, traditional, and hybrid approaches to project success: Is hybrid a poor second choice? Proj. Manag. J. 2021, 52, 161-175. [CrossRef]

88. Imam, H.; Zaheer, M.K. Shared leadership and project success: The roles of knowledge sharing, cohesion and trust in the team. Int. J. Proj. Manag. 2021, 39, 463-473. [CrossRef]

89. Zuo, J.; Zhao, X.; Nguyen, Q.B.M.; Ma, T.; Gao, S. Soft skills of construction project management professionals and project success factors: A structural equation model. Eng. Constr. Archit. Manag. 2018, 25, 425-442. [CrossRef]

90. Castro, M.S.; Bahli, B.; Barcaui, A.; Figueiredo, R. Does one project success measure fit all? An empirical investigation of Brazilian projects. Int. J. Manag. Proj. Bus. 2021, 14, 788-805. [CrossRef]

91. Zaman, U.; Nawaz, S.; Tariq, S.; Humayoun, A.A. Linking transformational leadership and "multi-dimensions" of project success: Moderating effects of project flexibility and project visibility using PLS-SEM". Int. J. Manag. Proj. Bus. 2020, 13, 103-127. [CrossRef]

92. Ma, L.; Fu, H. Exploring the influence of project complexity on the mega construction project success: A qualitative comparative analysis (QCA) method. Eng. Constr. Archit. Manag. 2020, 27, 2429-2449. [CrossRef]

93. Zaman, U.; Jabbar, Z.; Nawaz, S.; Abbas, M. Understanding the soft side of software projects: An empirical study on the interactive effects of social skills and political skills on complexity-performance relationship. Int. J. Proj. Manag. 2019, 37, 444-460. [CrossRef]

94. Zaman, U.; Nadeem, R.D.; Nawaz, S. Cross-country evidence on project portfolio success in the Asia-Pacific region: Role of CEO transformational leadership, portfolio governance and strategic innovation orientation. Cogent Bus. Manag. 2020, 7, 1727681. [CrossRef] 